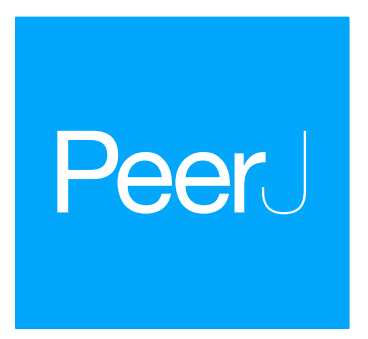

Submitted 13 September 2018 Accepted 7 February 2019 Published 13 March 2019

Corresponding author Javier Manjarrez, jsilva@uaemex.mx

Academic editor

Ann Hedrick

Additional Information and Declarations can be found on page 15

DOI 10.7717/peerj.6601

Copyright

2019 Valencia-Flores et al.

Distributed under

Creative Commons CC-BY 4.0

OPEN ACCESS

\section{Microgeographic variation in body condition of three Mexican garter snakes in central Mexico}

\author{
Erika Valencia-Flores ${ }^{1}$, Crystian S. Venegas-Barrera ${ }^{2}$, Victor Fajardo ${ }^{3}$ and \\ Javier Manjarrez ${ }^{1}$ \\ ${ }^{1}$ Facultad de Ciencias, Universidad Autónoma del Estado de México, Toluca, Estado de México, México \\ ${ }^{2}$ Tecnológico Nacional de México/Instituto Tecnológico de Ciudad Victoria, Ciudad Victoria, Tamaulipas, \\ México \\ ${ }^{3}$ Facultad de Medicina Veterinaria y Zootecnia, Universidad Autónoma del Estado de México, Toluca, Estado \\ de México, Mexico
}

\section{ABSTRACT}

Background. Geographic variation in body size and condition can reveal differential local adaptation to resource availability or climatic factors. Body size and condition are related to fitness in garter snakes (Thamnophis), thus good body condition may increase survival, fecundity in females, and mating success in males. Phylogenetically related species in sympatry are predicted to exhibit similar body condition when they experience similar environmental conditions. We focused on interspecific and geographical variation in body size and condition in three sympatric Mexican garter snakes from the highlands of Central Mexico.

Methods. We assessed SVL, mass, and body condition (obtained from Major axis linear regression of ln-transformed body mass on $\ln$-transformed SVL) in adults and juveniles of both sexes of Thamnophis eques, T. melanogaster, and T. scalaris sampled at different locations and ranges from 3-11 years over a 20-year period.

Results. We provide a heterogeneous pattern of sexual and ontogenic reproductive status variations of body size and condition among local populations. Each garter snake species shows locations with good and poor body condition; juvenile snakes show similar body condition between populations, adults show varying body condition between populations, and adults also show sex differences in body condition. We discuss variations in body condition as possibly related to the snakes' life cycle differences.

Subjects Ecology, Zoology

Keywords Ontogenic reproductive status, Geographical variation, Interspecific variation, Central Mexico Highlands, Thamnophis, Diet

\section{INTRODUCTION}

Organisms usually respond to differences in environmental conditions by exhibiting local adaptation in phenotypic traits. Geographic variation in phenotypic traits associated with body size and condition can reveal differential adaptation of local populations to local biotic and abiotic fluctuations as presence of related species, resource availability, or climatic factors (Bronikowski \& Arnold, 1999; Bronikowski, 2000; Miller et al., 2011). Also, geographic variation in body size and body condition can reveal fundamental variation 
in selective pressures, especially in reptiles such as snakes (Bronikowski \& Arnold, 1999; Miller et al., 2011). Thus, analyses of geographic variation in body size and condition are important to explain locally variable adaptations that produce morphological diversity in snake species. Geographic variation in body condition comes from many causes, including phenotypic plasticity (Krause, Burghardt \& Gillingham, 2003) or microevolutionary change among natural populations (Bronikowski, 2000). These population differences may arise from geographic variation in food resources (Bronikowski \& Arnold, 1999), climate (Ashton, 2001), or intra-inter species interactions (e.g., Kurzava \& Morin, 1994).

Body condition is an expression of weight and length (size-adjusted body mass), and it is correlated with body reserves (Hayes \& Shonkwiler, 2001), especially with energy stores in the liver, muscle, and fat of snakes (Bonnet et al., 1998; Falk, Snow \& Reed, 2017). During periods of low resource availability, starvation and low body reserves are a good predictor of mortality (Shine et al., 2001; Kissner \& Weatherhead, 2005), decreased reproductive status (Naulleau \& Bonnet, 1996; Lind \& Beaupre, 2015; Catherine, LeMaster \& Lutterschmidt, 2018), and low growth rates in snakes (Bronikowski, 2000).

Thus, there is a relation between body size and condition with fitness, but in different ways for the two sexes, especially with reproductive status of snakes. For example, a good body condition may be associated with enhanced survival of both sexes of garter snakes, greater fecundity in female garter snakes, and increased mating success for males (Naulleau \& Bonnet, 1996); thereby, a reduction in body condition may reduce reproductive capacity (Lind \& Beaupre, 2015). Conversely, adult female snakes in poor condition that are carrying eggs experience greater mortality (Madsen \& Shine, 1993; Brown \& Weatherhead, 1997; Shine et al., 2001).

Additionally, phylogenetically related species in sympatry are predicted to exhibit similar body condition when they have similar ecology, because they share similar evolutive history, interspecific interactions and selective pressures (i.e., Yom-Tov \& Geffen, 2006; Koyama et al., 2015; Sivan et al., 2015). For example, closely related species of garter snakes with highly overlapping ranges in Mexico, Thamnophis melanogaster and T. eques, show similar patterns of neonate body condition as a function of date of birth (Manjarrez \& San-Roman-Apolonio, 2015).

To understand the complex evolution of body condition, we studied interspecific and geographical variation in traits known to be associated with body condition in three sympatric Mexican garter snakes (Thamnophis sp.) inhabiting five sites from the highlands of Central Mexico. Given that the geographic distribution of these three garter snakes comprises a range of different environmental conditions, we hypothesized that traits associated with body condition of snakes would potentially reveal a pattern of geographical variation among local populations that could be influenced by dietary differences, ontogenic reproductive status (juvenile, adult), and sex of snakes. We predicted that the geographic variation in body condition in garter snakes is influenced by diet differences among populations, such that body condition would vary among populations. We discuss possible body condition differences as they are related to life cycle differences.

In this study we assessed snout-vent length (SVL), mass, and body condition in adults and juveniles of both sexes from three sympatric garter snakes in the Central Mexican 

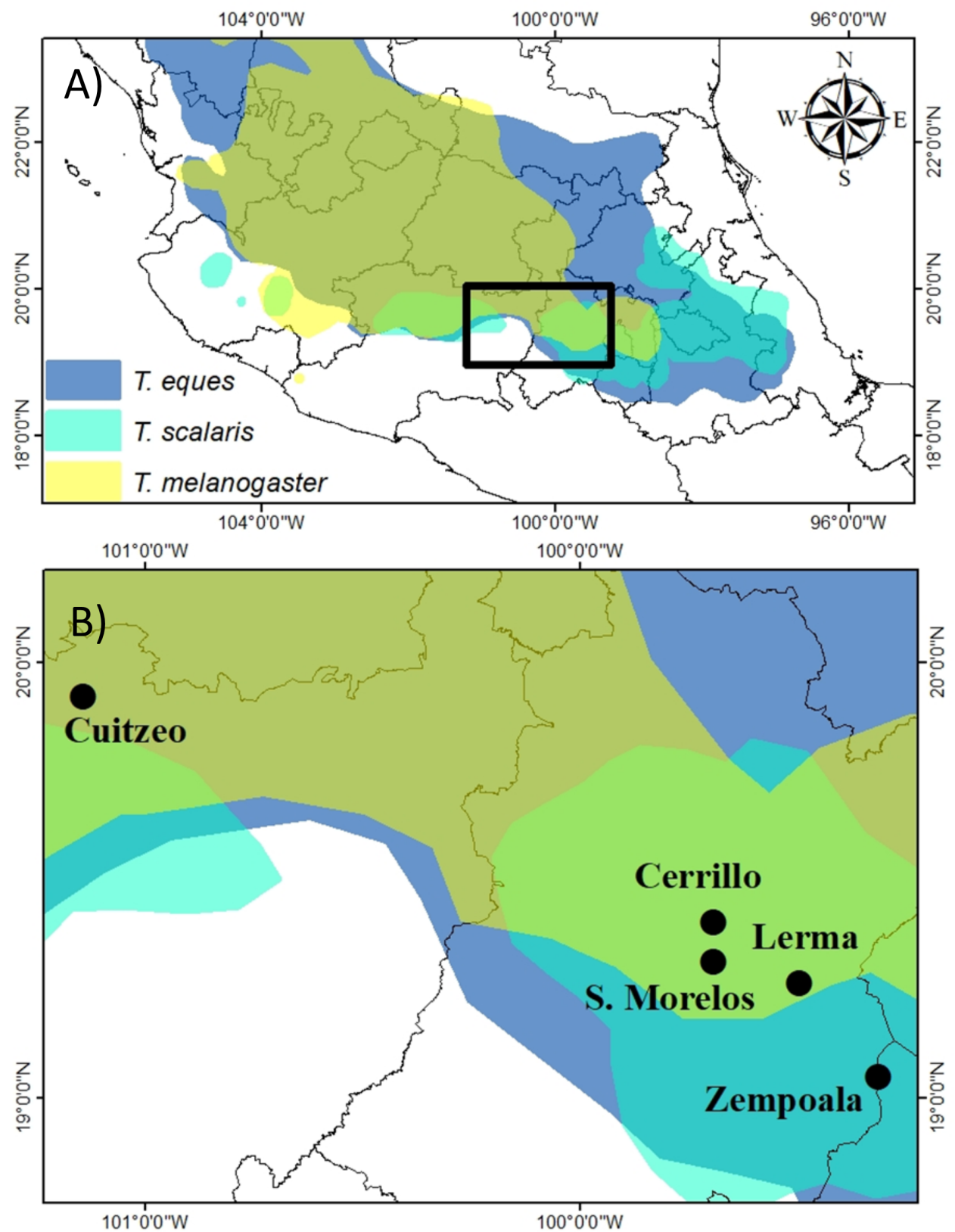

Figure 1 (A) Geographic distribution of T. eques, T. melanogaster and T. scalaris in Central Mexico (digitalized from Rossman, Ford \& Seigel, 1996) and (B) study locations in the Rio Lerma drainage. Full-size DOI: 10.7717/peerj.6601/fig-1

Highlands (Fig. 1); Mexican garter snake (Thamnophis eques), Mexican Black-bellied garter snake (T. melanogaster), and Longtail Alpine garter snake (T. scalaris). They are grouped within the well-supported clade of garter snakes composed of species found mostly in Mexico (Queiroz, Lawson \& Lemos-Espinal, 2002; Guo et al., 2012; McVay \& Carstens, 2013). Garter snakes are the most abundant snake genus in Central Mexico (Flores-Villela, Canseco-Márquez \& Ochoa-Ochoa, 2010). Garter snakes exhibit substantial variation within 
and among species in certain aspects of morphology, behavior and physiology, a pattern specially demonstrated in two North American species recognized as examples of evolution (Burghardt \& Schwartz, 1999). There is considerable intra-interspecific variation in color patterns, body size, diet, habitat, resistance to toxic prey, reproductive characteristcs and behavior that the patterns of the constraints may vary among poplations (Burghardt \& Schwartz, 1999; Rossman, Ford \& Seigel, 1996). In general, garter snakes are sexually dimorphic in body size (Shine, 1993) with females regularly larger than males (Shine, 1994). Almost all studies comparing the body condition of garter snake species were conducted separately for each sex and rarely have been combined in a single study; therefore, there is scarce information of possible sex differences in garter snake body condition, but see (Rollings et al., 2017).

We chose the species T. eques, T. melanogaster, and T. scalaris that occur in Central Mexico because there are no studies that describe the body condition or its possible interspecific or spatial variations under natural conditions for these three species. Only one study of T. melanogaster and T. eques detected body condition patterns in offspring born from females caught in the wild (Manjarrez \& San-Roman-Apolonio, 2015). For both species, body condition of neonates differed by being lower in the early season and higher in the late season. Snout-vent length of neonates and mean mass of neonates per litter did not change throughout the birth season (Manjarrez \& San-Roman-Apolonio, 2015).

Thamnophis eques is widely distributed from Central Mexico to southern New Mexico and Arizona in the United States (Rossman, Ford \& Seigel, 1996). It is a generalist snake because it preys on both terrestrial and aquatic prey such as frogs, fish and tadpoles, and occasionally, mice and lizards (Drummond \& Macías García, 1989; Manjarrez, 1998; Manjarrez, Pacheco-Tinoco \& Venegas-Barrera, 2017). Thamnophis melanogaster is endemic to the Central Mexican Plateau. It is a semiaquatic snake present at the edge of water bodies and preys mostly on tadpoles, fish, and leeches (Rossman, Ford \& Seigel, 1996; Manjarrez, Macías García \& Drummond, 2013). Thamnophis scalaris is also endemic to Central Mexico (Rossman, Ford \& Seigel, 1996). It inhabits forests and grasslands, where it specializes on earthworms, although it can eat vertebrates such as lizards and mice (Manjarrez, Venegas-Barrera \& García-Guadarrama, 2007).

\section{MATERIALS \& METHODS}

In Central Mexico, we irregularly sampled garter snakes at eight different locations in the Rio Lerma drainage (Fig. 1A) over a period of 20 years, however, we selected only those five populations (Fig. 1B) with more than 24 records of snakes, which allowed us to make spatial and sex comparisons. We selected the records of snakes collected over three different years for T. scalaris (2003, 2005, and 2010) at three locations; seven years for T. melanogaster (2005-2011), at two locations, and eleven years for T. eques (2000-2003, 2005-2011) at three locations (Table 1). Locations are separated by $92.6 \mathrm{Km}$ of mean distance $(\mathrm{SD}=$ $80 \mathrm{Km}$, range $9.5-215 \mathrm{~km}$ ). Among the five sites, mean annual temperature ranged from $13.7^{\circ}-18.1^{\circ} \mathrm{C}$ and mean annual precipitation ranged from $116 \mathrm{~mm}-755.8 \mathrm{~mm}$ (Table 1). Thamnophis eques were captured between March and November, T. melanogaster between January and December, and T. scalaris between June and November. 


\begin{tabular}{|c|c|c|c|c|c|}
\hline Locality & Garter snake present & $\begin{array}{l}\text { Coordinates N, } \\
\text { W (Datum WGS84) }\end{array}$ & $\begin{array}{l}\text { Elevation } \\
(\mathbf{m})\end{array}$ & $\begin{array}{l}\text { Mean annual } \\
\text { temperature }\left({ }^{\circ} \mathrm{C}\right)\end{array}$ & $\begin{array}{l}\text { Mean annual } \\
\text { precipitation }(\mathrm{mm})\end{array}$ \\
\hline Lerma, Estado de México & $\begin{array}{l}\text { T. eques, } \\
\text { T. melanogaster, } \\
\text { T. scalaris }\end{array}$ & $\begin{array}{l}19^{\circ} 14^{\prime} 28.73^{\prime \prime}, \\
99^{\circ} 29^{\prime} 41.14^{\prime \prime}\end{array}$ & 2,573 & 15.8 & 158.7 \\
\hline Cerrillo, Estado de México & T. eques & $\begin{array}{l}19^{\circ} 24^{\prime} 20.86^{\prime \prime}, \\
99^{\circ} 41^{\prime} 41.05^{\prime \prime}\end{array}$ & 2,550 & 13.7 & 116 \\
\hline S. Morelos, Estado de México & T. scalaris & $\begin{array}{l}19^{\circ} 18^{\prime} 49.58^{\prime \prime}, \\
99^{\circ} 41^{\prime} 29.07^{\prime \prime}\end{array}$ & 2,750 & 13.8 & 746.9 \\
\hline Cuitzeo, Michoacan & $\begin{array}{l}\text { T. eques, } \\
\text { T. melanogaster, }\end{array}$ & $\begin{array}{l}19^{\circ} 55^{\prime} 32.83^{\prime \prime}, \\
101^{\circ} 08^{\prime} 26.78^{\prime \prime}\end{array}$ & 1,837 & 18.1 & 755.8 \\
\hline Zempoala, Morelos & T. scalaris & $\begin{array}{l}19^{\circ} 02^{\prime} 53.40^{\prime \prime}, \\
99^{\circ} 18^{\prime} 44.54^{\prime \prime}\end{array}$ & 2,800 & 14.2 & 514 \\
\hline
\end{tabular}

We found snakes by searching under rocks and tree trunks, and some were found simply basking on the ground. All snakes were captured by hand. Adult females were carefully examined for the presence of embryos, and those identified as gravid were excluded from analysis. Measurements of captured snakes included sex (visual inspection of tail-base breadth or by everting the male hemipenes in small snakes), snout-vent length (SVL), and mass (measured on an electronic scale $( \pm 0.1 \mathrm{~g})$ ). Dietary differences among the localities were examined by analysis of stomach contents from T. eques and T. melanogaster. We obtained stomach contents by making the snakes regurgitate by abdominal palpation (Fitch, 1987). For T. scalaris, no stomach contents were recorded. Immediately after processing, snakes were released where they had been captured.

\section{Analysis}

Individual body condition was calculated using residuals from the Major axis (MA) linear regression of $\ln$-transformed body mass on $\ln$-transformed SVL. This MA residual index is considered an excellent estimator of true snake body condition because it shows a strong association with body fat mass but not SVL (Falk, Snow \& Reed, 2017). The condition that the MA linear regression is unbiased in with respect to size is considerable for hypothesis testing, because an absence of correlation with size permit to compare MA residual index across individuals of different size ranges. Particularly, only $2 \%$ of the variation in the MA residual index is associated with SVL (Falk, Snow \& Reed, 2017). This regression was significant for all species (T. eques, $r=0.90, P<0.0001 ;$ T. melanogaster, $r=0.93, P<0.0001 ;$ T. scalaris, $r=0.95, P<0.0001)$. Residuals were used to categorize body condition, with positive residuals corresponding to individuals with good body condition and negative residuals corresponding to individuals with poor body condition (Weatherhead \& Brown, 1996; Falk, Snow \& Reed, 2017). In this way, the average condition by location is interpreted as good or bad condition by location for each species.

Because the optimal body condition should approximate the true body condition of the snakes and should be unbiased with respect to body size, we evaluated this relationship with Kendall rank correlation coefficient to test for a correlation between body condition and ln-transformed SVL as a measure of size and estimated the percent variation in body 


\begin{tabular}{|c|c|c|c|c|c|c|}
\hline & & \multicolumn{2}{|c|}{ Location } & \multicolumn{2}{|c|}{ Year } & Sex \\
\hline \multicolumn{7}{|c|}{ T. melanogaster } \\
\hline \multicolumn{2}{|c|}{ body condition } & \multicolumn{2}{|c|}{1.25} & \multicolumn{2}{|c|}{$3.76^{* *}$} & 1.54 \\
\hline \multicolumn{2}{|l|}{ SVL } & \multicolumn{2}{|c|}{$21.58^{* * *}$} & \multicolumn{2}{|c|}{$6.56^{* * *}$} & 0.18 \\
\hline \multicolumn{2}{|l|}{ mass } & \multicolumn{2}{|c|}{$29.21^{* * *}$} & \multicolumn{2}{|c|}{$5.50^{* * *}$} & 0.00 \\
\hline \multicolumn{7}{|l|}{ T. eques } \\
\hline \multicolumn{2}{|c|}{ body condition } & \multicolumn{2}{|c|}{$5.59^{*}$} & \multicolumn{2}{|c|}{$2.56^{*}$} & 0.21 \\
\hline SVL & & \multicolumn{2}{|c|}{$12.08^{* * *}$} & \multicolumn{2}{|c|}{$22.75^{* * *}$} & 0.99 \\
\hline mass & & \multicolumn{2}{|c|}{$7.47^{* *}$} & \multicolumn{2}{|c|}{$20.82^{* * *}$} & 1.66 \\
\hline \multicolumn{7}{|l|}{ T. scalaris } \\
\hline \multicolumn{2}{|c|}{ body condition } & \multicolumn{2}{|c|}{$14.06^{* * *}$} & \multicolumn{2}{|c|}{$14.32^{* * *}$} & 0.23 \\
\hline SVL & & \multicolumn{2}{|c|}{$7.12^{* *}$} & \multicolumn{2}{|c|}{0.34} & 0.67 \\
\hline mass & & \multicolumn{2}{|c|}{2.42} & \multicolumn{2}{|c|}{$3.73^{*}$} & 1.10 \\
\hline \multicolumn{7}{|l|}{ 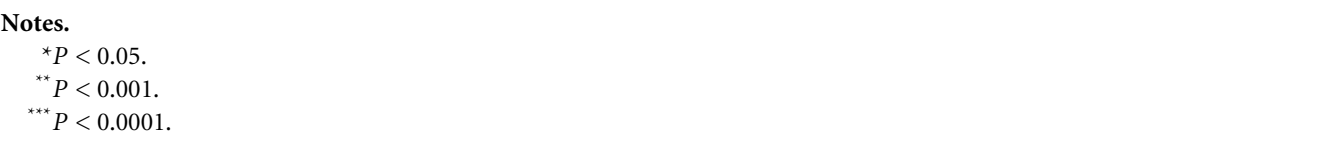 } \\
\hline \multicolumn{7}{|c|}{$\begin{array}{l}\text { Table } 3 \text { Sex ratio (male:female) of } T \text {. eques, T. melanogaster, and } T \text {. scalaris for each population col- } \\
\text { lected from Central Mexican Highlands ( } d f=1 \text { for all tests). }\end{array}$} \\
\hline & \multicolumn{2}{|c|}{ T. eques } & \multicolumn{2}{|c|}{ T. melanogaster } & \multicolumn{2}{|c|}{ T. scalaris } \\
\hline & Sex ratio & $\chi^{2}$ test $(P)$ & Sex ratio & $\chi^{2}$ test $(P)$ & Sex ratio & $\chi^{2}$ test $(P)$ \\
\hline Lerma & $1: 1$ & $0.45(0.49)$ & $1: 1$ & $2.0(0.15)$ & $1: 1.5$ & $12.46(0.0004)$ \\
\hline Cuitzeo & $1: 2$ & $4.33(0.03)$ & $1: 1.4$ & $14.9(0.0001)$ & & \\
\hline Cerrillo & $1: 3$ & $6.76(0.009)$ & & & & \\
\hline S. Morelos & & & & & $1: 1.7$ & $9.94(0.001)$ \\
\hline Zempoala & & & & & $0: 23$ & $23.0(<0.0001)$ \\
\hline
\end{tabular}

condition. Also, with the coefficient of determination $\left(R^{2}\right)$, we estimated the percent variation in body condition and mass that can be explained by SVL.

\section{Geographic comparison}

The SVL and mass of snakes were transformed with natural logarithms prior to analyses. We utilized one-way analyses of variance (ANOVA) to compare body condition, SVL, and mass as dependent variables among populations of each species. In these analyses, we pooled male and female snakes because a three-way ANOVA (locality, year, and sex) indicated that body condition, SVL and mass within each species did not differ between sexes, but did differ among locality and between years (Table 2). We used a Chi-square goodness-of-fit test to determine if sex ratio among species was different than 1:1 (Table 3). Statistical significance was assessed at $\alpha=0.05$. All data are reported as means $\pm 1 S D$.

\section{Sexual and size status comparison}

Each snake was assigned an ontogenic reproductive status (juvenile, adult) according to size at capture (adult snakes $>39.0,33.0$, and $34 \mathrm{~cm} \mathrm{SVL}$ for T. eques, T. melanogaster 
and T. scalaris, respectively; (Manjarrez, 1998; Manjarrez, Venegas-Barrera \& GarcíaGuadarrama, 2007). We performed a discriminant function analysis (DFA) for testing intraspecific differences (between location, sex, and size category) according to the mean of the exploratory variables (SVL, mass, and body condition) and for generating linear combinations that classify snakes as a function of their morphological traits associated with snake body condition. The grouping variables were location, sex (male, female) and ontogenic reproductive status. DFA is an inferential, descriptive multivariate procedure for testing differences between groups according to the mean of all variables and for generating linear combinations that classify objects as a function of their characteristics (Statistica, ver. 12; StatSoft, Inc., Tulsa, OK, USA).

The objective of DFA was to test differences between groups and identify which variables discriminate between two or more groups. Comparisons between groups were performed under the null hypothesis that morphological traits between categories of grouping variables were similar, and the estimated value was contrasted with the theoretical value of the F-distribution. We employed a probability of 0.05 to test the hypothesis, where $\mathrm{P}$ values lower than 0.05 were associated with groups of snakes showing different morphological traits, whereas values greater than or equal to 0.05 were associated with groups with similar morphological traits. The canonical average of the observations from each category (centroid) for the significant roots (canonical scores) was plotted, which reflects morphological variations between categories of grouping variables. The position of the centroids was interpreted using the variables that contributed most to discriminating between groups.

We chose those variables that exhibited a coefficient of the factor structure higher than 0.5 or lower than -0.5 . The coefficients represent the correlation between the original variables and the roots. We applied one-way ANOVAs or Student- $t$ with Statistica software (ver. 8.0; StatSoft, Tulsa, OK, USA) when only one morphological variable exhibited a coefficient of the factor structure higher than 0.5 or lower than -0.5 .

This study received the approval of field permit (Secretaria del Medio Ambiente y Recursos Naturales \#07164) and the ethics committee of the Universidad Autónoma del Estado de México (Number 4047/2016SF). All subjects were treated humanely on the basis of guidelines outlined by the American Society of Ichthyologists and Herpetologists (ASIH, 2004).

\section{RESULTS}

The biggest species of garter snake was T. eques with a mean body size of SVL $43.43 \pm 17.57$ $\mathrm{cm}$ (range 12.51-81.30), mass of $55.62 \pm 60.56 \mathrm{~g}$ (range 1.40-335.86, $n=253$ ). Thamnophis melanogaster was slightly larger than T. scalaris (T. melanogaster: SVL $29.17 \pm 41 \mathrm{~cm}$ [range 14.40-66.0], mass $19.10 \pm 23.3 \mathrm{~g}$ [range 1.62-196.0], $n=686$; T. scalaris: SVL $28.70 \pm 9.21$ $\mathrm{cm}$ [range 12.10-53.0], mass $16.44 \pm 12.59 \mathrm{~g}$ [range 1.30-60.70], $n=80$ ).

The number of males and females collected was independent of locations sampled for $T$. melanogaster $\left(\chi^{2}=0.001, d f=1, P=0.97\right)$, and T. scalaris $\left(\chi^{2}=3.69, d f=2, P=0.15\right)$, but dependent on location for T. eques $\left(\chi^{2}=10.4, d f=2, P=0.006\right)$. Considering all individuals collected, the sex ratio was biased toward females. For T. eques and T. scalaris, 


\begin{tabular}{|c|c|c|c|c|c|c|}
\hline & $\begin{array}{l}T . \text { eques } \\
n=253\end{array}$ & $R^{2}$ & $\begin{array}{l}\text { T. melanogaster } \\
n=686\end{array}$ & $R^{2}$ & $\begin{array}{l}\text { T. scalaris } \\
n=80\end{array}$ & $R^{2}$ \\
\hline Ln-mass & $0.77^{*}$ & 0.84 & $0.81^{*}$ & 0.88 & $0.80^{*}$ & 0.92 \\
\hline Body condition & $-0.25^{*}$ & 0.12 & $-0.19^{*}$ & 0.08 & $-0.21^{*}$ & 0.05 \\
\hline
\end{tabular}

Notes.

${ }^{\star} P<.0001$.

the sex ratio was skewed toward females in two or three locations analyzed (Table 3), whereas the sex ratio for T. melanogaster was biased toward females in Cuitzeo but not in Lerma (Table 3). For T. scalaris the female bias was very distinct, especially Zempoala where no males were found (Table 3 ).

Both body condition (residuals from MA linear regression of ln-transformed body mass on ln-transformed SVL) and body mass were related to ln-SVL in each garter snake (Table 4 ). The $R^{2}$ values suggest that more than $80 \%$ of the variation in body mass is explained by SVL, and less than $12 \%$ of the variation in body condition is explained by SVL (Table 4).

\section{Geographic comparison Thamnophis eques}

For the three locations that we analyzed for T. eque s (Lerma, Cerrillo and Cuitzeo), we observed a difference in mean body condition. Thamnophis eques from Lerma showed a mean poor body condition that was the lowest of the three populations $\left(F_{2,250}=10.7\right.$, $P<0.0001$; Fig. 2), although snakes in this location were significantly larger than in the other two (ln-SVL $F_{2,250}=6.7, P=0.001$ ). Conversely, $T$. eques from Cuitzeo showed the best body condition, but the shortest length (Fig. 2). Mean body mass was not different between locations of $T$. eques ( $\ln$-mass $F_{2,250}=2.2, P=0.11$ ).

\section{Thamnophis melanogaster}

For T. melanogaster, the statistical test did not detect a significant difference in mean body condition between the two locations, Lerma and Cuitzeo $\left(F_{1,684}=3.1, P=0.07\right)$. However, the Lerma snakes were significantly larger (ln-SVL $F_{1,684}=42.3, P<0.0001$ ), and heavier than those collected in Cuitzeo (ln-mass $F_{1,684}=56.4, P<0.0001$; Fig. 2).

\section{Thamnophis scalaris}

In this species the mean SVL and mass showed no differences among the three locations analyzed (Lerma, S. Morelos and Zempoala, ln-SVL $F_{2,77}=1.55, P=0.21$; ln-mass $\left.F_{2,77}=0.58, P=0.56\right)$, however, mean body condition was good in the individuals from S. Morelos and poor for those from Zempoala $\left(F_{2,77}=20.9, P<0.0001\right.$; Fig. 2$)$.

\section{Sexual and size status comparison}

The results of DFA showed that each garter snake had a unique pattern of intraspecific differences. The body condition of juveniles T. eques was better than adults $\left(t_{227}=43.3\right.$, $P<0.0001$ ). For T. melanogaster and T. scalaris the body condition of juveniles and adults was similar $\left(t_{684}=0.01, P<0.99 ; t_{78}=1.5, P=0.13\right.$, respectively $)$. 

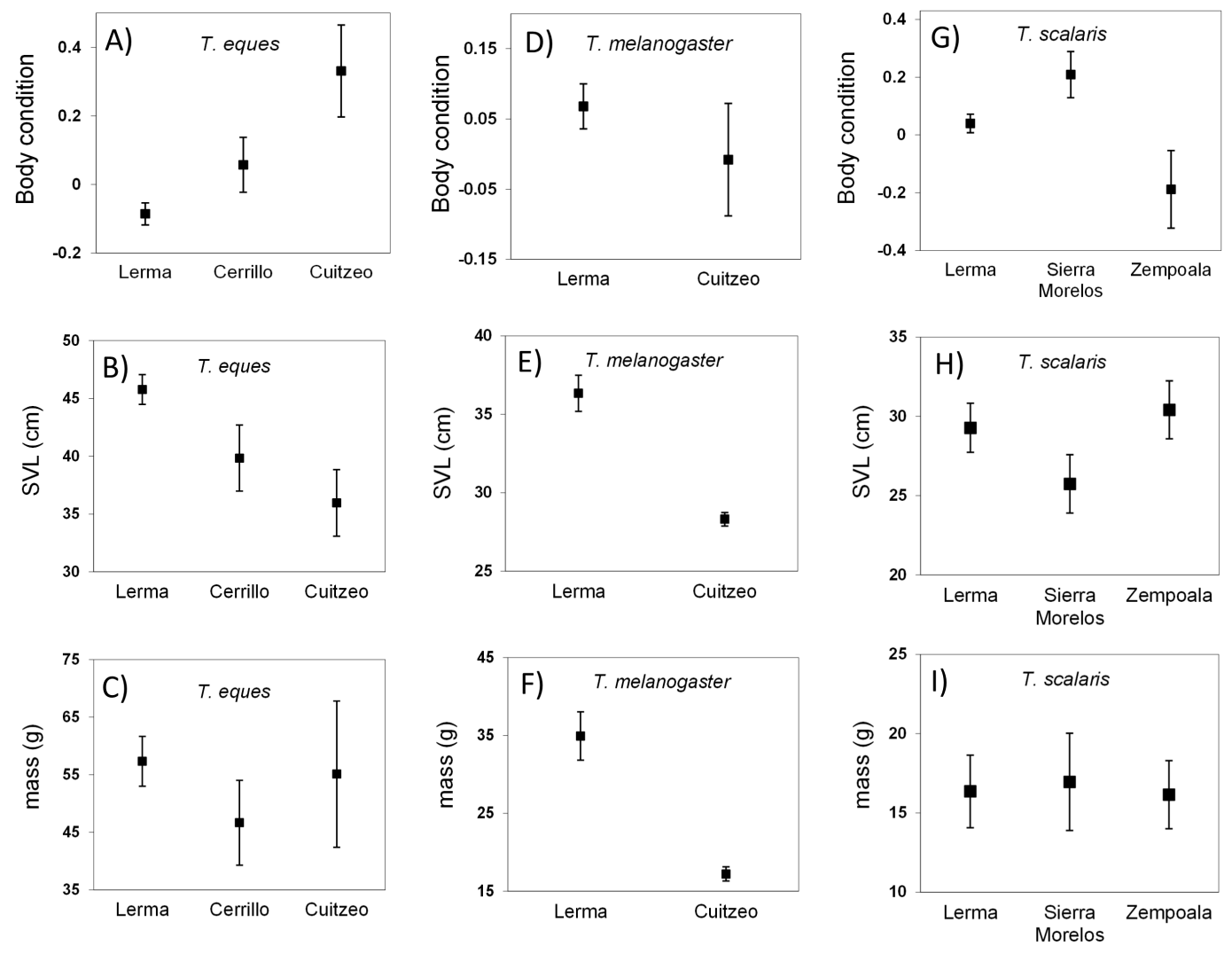

Figure 2 Body condition, SVL and mass (mean $\pm 1 \mathrm{SE})$ of wild-caught snakes T. eques (A-C), T. melanogaster (D-F), and T. scalaris (G-I). Snakes collected from locations in the Central Mexican Highlands over a period of 20 years. Body condition obtained of residuals from MA linear regression of ln-transformed body mass on ln-transformed SVL.

Full-size DOI: 10.7717/peerj.6601/fig-2

\section{Thamnophis eques}

Juvenile females of Cuitzeo had a better body condition than juvenile females of Lerma $\left(t_{36}\right.$ $=2.17, P=0.03$ ), but body size (SVL and mass) were similar between Juvenile females of both locations $\left(F_{2,35}=2.9, P=0.06\right)$. Juvenile males $T$. eques have similar body size and body condition between Lerma and Cuitzeo.

Adult males T. eques of Cuitzeo had a higher mass $(140 \pm 130.1 \mathrm{~g})$ than adult males of Lerma $(57.2 \pm 32.7 \mathrm{~g})$ and Cerrillo $\left(49.7 \pm 18.7 \mathrm{~g}\right.$, ANOVA $\left.F_{2,37}=8.2, P<0.0001\right)$. Adult female T. eques of Lerma presented greater body size (SVL $59.0 \pm 9.3 \mathrm{~cm}$; mass 104.0 $\pm 68.1 \mathrm{~g}$ ) than adult females of Cerrillo (SVL $49.7 \pm 8.5 \mathrm{~cm}$; mass $71.0 \pm 41.3 \mathrm{~g}$; DFA $F_{4,158}=3.51, P=0.008$, Fig. 3).

\section{Thamnophis melanogaster}

Juvenile male T. melanogaster showed that body size traits and the body condition were similar between Lerma and Cuitzeo $\left(F_{1,165}=1.3, P=0.25\right)$. In the case of juvenile female T. melanogaster, SVL was greater in Lerma $(26.2 \pm 4.8 \mathrm{~cm})$ than Cuitzeo $(23.3 \pm 4.7 \mathrm{~cm})$, and body condition was similar between both locations $\left(F_{1,260}=5.06, P=0.02\right)$. 


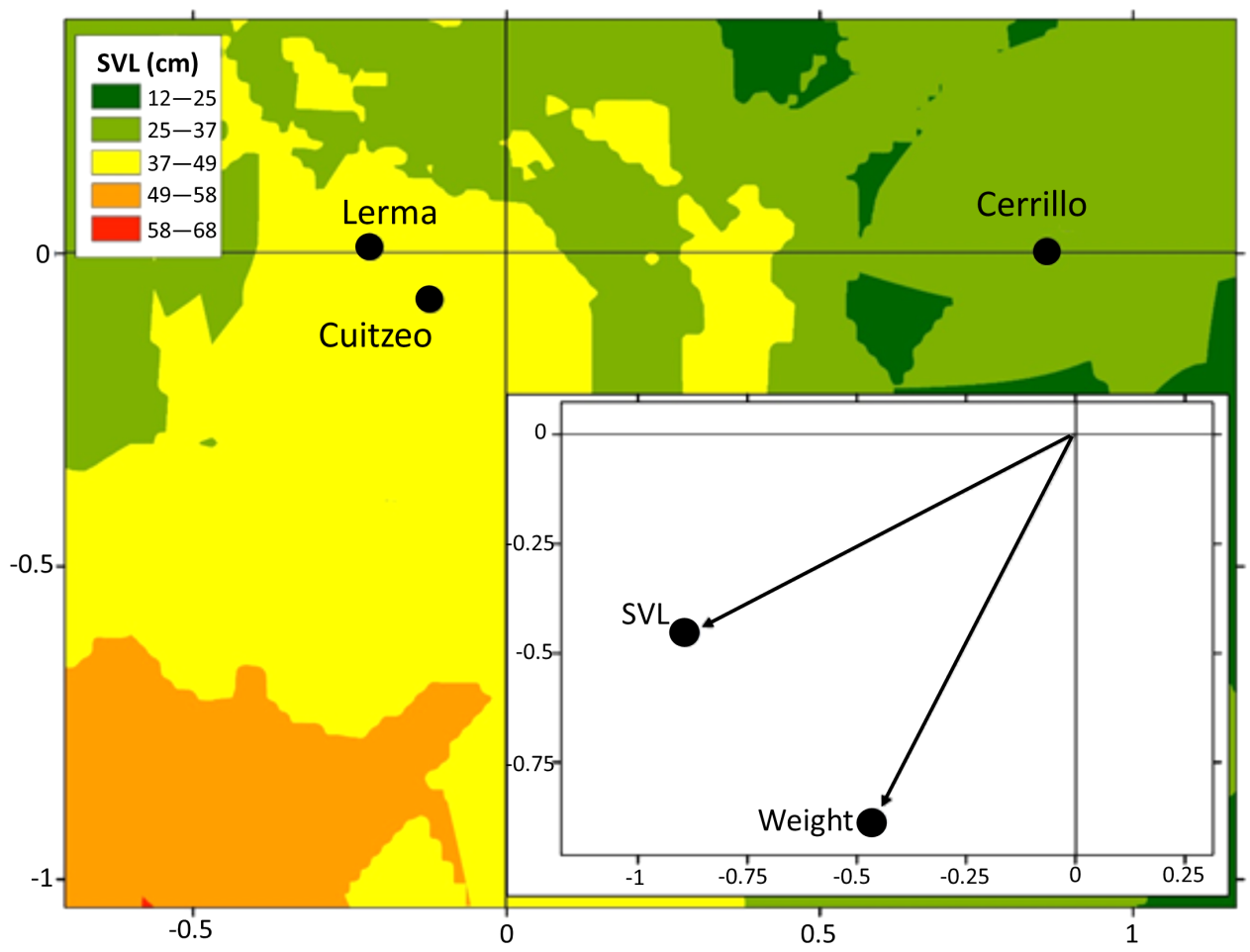

Figure 3 Average canonical position (centroid) for Lerma, Cerrillo and Cuitzeo, obtained from a discriminant function analysis of body condition traits in adult female T. eques and factor structure. Isoclines represent variation on SVL of snakes in Lerma, Cerrillo and Cuitzeo.

Full-size DOI: 10.7717/peerj.6601/fig-3

Adult T. melanogaster of both sexes presented a similar pattern. A better body condition in Lerma than Cuitzeo (males: $0.09 \pm 0.29$ vs. $-0.04 \pm 0.24$; females $0.18 \pm 0.34$ vs. $-0.07 \pm 0.33$ ), and similar body size (SVL and mass) between Lerma and Cuitzeo (males: $F_{1,86}=4.9, P=0.02$; females: $\left.F_{2,98}=8.07, P=0.0006\right)$.

\section{Thamnophis scalaris}

Only females T. scalaris (juvenile and adult) were enough to make comparisons between locations. Juvenile female T. scalaris of Zempoala were significantly longer, lighter, and had poor body condition than other locations. Lerma snakes showed lower SVL, mass, and average body condition, while snakes from Cerrillo and S. Morelos presented a better body condition, average SVL, and higher mass $\left(F_{1,165}=1.3, P=0.25\right.$, Fig. $\left.4 \mathrm{~A}\right)$.

Adult female T. scalaris of Lerma and Zempoala had poorer body condition than those of Cerrillo and S. Morelos $\left(F_{6,62}=8.4, P<0.0001\right.$, Fig. 4 C).

\section{Stomach contents}

Of the total snakes collected by species in this study, $17.4 \%$ (44 T. eques) and $13.3 \%$ (91 T. melanogaster) had some prey in the stomach. The diet of T. eques in Lerma and Cerrillo included aquatic prey (leeches, fish and tadpoles) and amphibious prey (frogs). The terrestrial prey (earthworms and mice) were only ingested by T. eques at Cerrillo (Table 5). At Cuitzeo, T. eques consumed mainly fish and only some leeches (Table 5). 

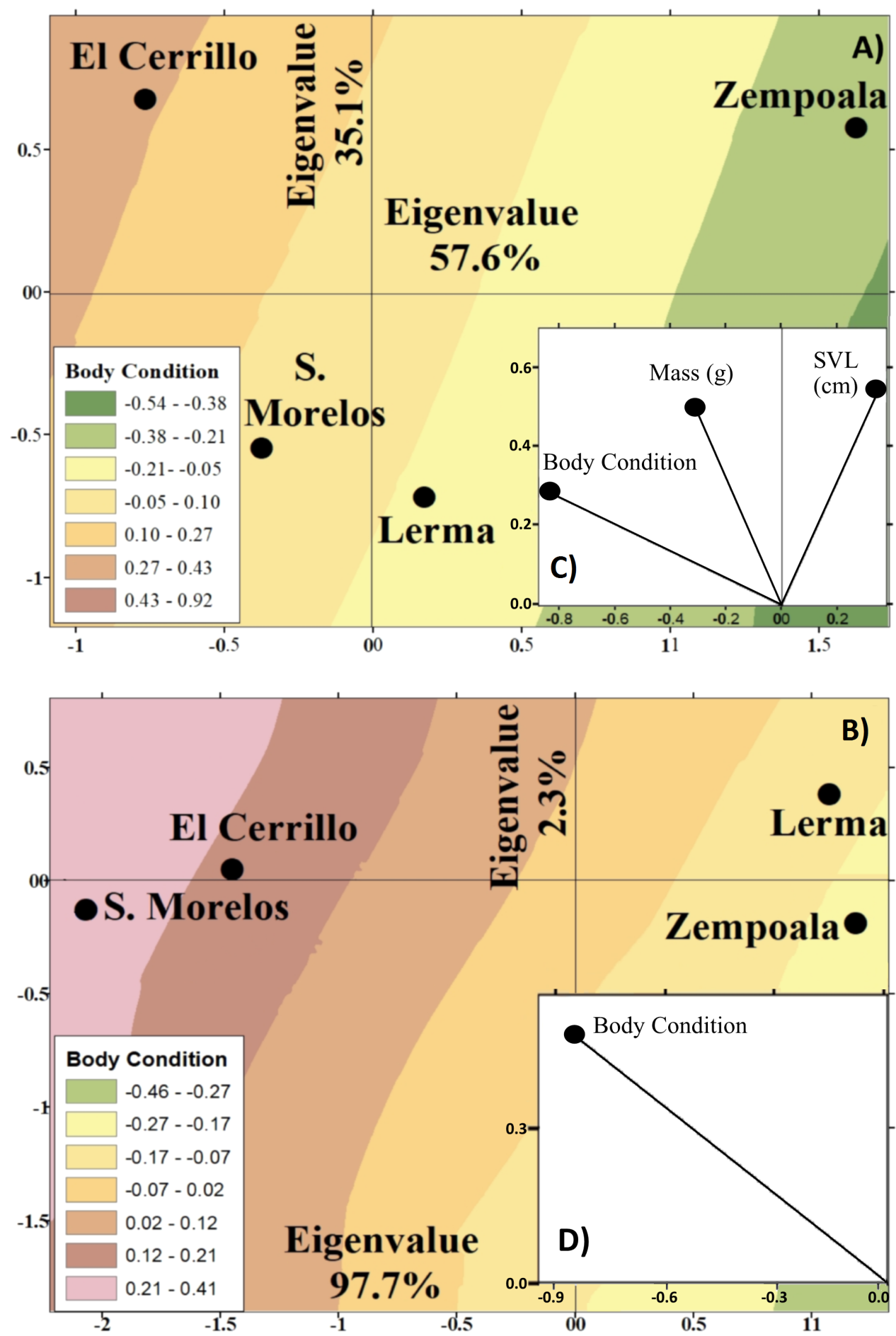

Figure 4 Canonical position of the centroids of juvenile (A) and adult (B) females of garter snakes T. scalaris captured from Lerma, Cerrillo, S. Morelos and Zempoala. Centroids obtained from a discriminant function analysis and the variables with the greatest discrimination between locations ( $\mathrm{C}$ and D). Isoclines represent variation of body conditions of snakes in Lerma, Cerrillo, S. Morelos and Zempoala. 


\begin{tabular}{llll}
\hline $\begin{array}{l}\text { Table } 5 \\
\text { the Lerma, Cerrillo and Cuitzeo locations. Percentages by location in parentheses. }\end{array}$ & Eumer of stomaster in \\
Prey & Lerma & El Cerrillo & Cuitzeo \\
\hline Thamnophis eques & & & \\
Fish & $2(22.2)$ & $3(12.5)$ & $10(90.9)$ \\
Leech & $4(44.4)$ & 0 & $1(9.1)$ \\
Tadpole & $1(11.1)$ & $3(12.5)$ & 0 \\
Earthworm & 0 & $7(29.2)$ & 0 \\
Frog & $2(22.2)$ & $5(20.8)$ & 0 \\
Mouse & 0 & $6(25)$ & 0 \\
Thamnophis melanogaster & & & \\
Fish & $30(88.2)$ & & $54(100)$ \\
Leech & $2(5.9)$ & & 0 \\
Tadpole & 0 & & 0 \\
Earthworm & 0 & 0 \\
Axolotl & $2(5.9)$ & & 0 \\
\hline
\end{tabular}

The diet of T. melanogaster included more prey items at Lerma than in Cuitzeo. At Lerma, the fish were the main prey and leech and axolotl were ingested in similar proportion (Table 5). At Cuitzeo, T. melanogaster snakes contained only fishes.

\section{DISCUSSION}

In this study, we provide a heterogeneous pattern of sexual and ontogenic reproductive status variations in body size and condition among populations of three sympatric garter snakes collected in the Central Mexico Highlands over several years. We found: (1) each garter snake species shows good and poor body condition in a variety of locations, (2) juvenile garter snakes show similar body condition between populations, (3) adults show different body conditions between populations, and (4) adults also show sex differences in body condition. Thus, geographical differences in body condition were present in juvenile female T. eques, both sexes of adult T. melanogaster, and juvenile and adult females of T. scalaris.

Addittionally, dietary differences were checked to associated them with body condition differences between the localities. Thamnophis eques snakes where fish were the predominant prey (Cuitzeo) had significantly better body condition than snakes that fed on fish and other aquatic, terrestrial and amphibious prey (Lerma and Cerrillo). Overall, although T. eques snakes from Lerma and Cerrillo have greater body size than Cuitzeo snakes, adult females were significantly heavier than females from Cuitzeo. On the other hand, T. melanogaster snakes where more prey items were ingested (Lerma), had significantly greater body size (SVL and mass) and better body condition (adult males and females) than T. melanogaster snakes where fish were the only prey (Cuitzeo).

We hypothesized that body condition of garter snakes would reveal a pattern of geographical variation influenced by ontogenic reproductive status (juvenile, adult), sex, and diet differences among populations. Several problems may confound these 
inter- and intraspecific patterns of differences in body condition because each responds to complex interactions between sexual and ontogenic reproductive status with local environmental variables and local resource availability (Congdon, 1989; Shine et al., 2001). Thus, the differences in body condition between sites may result from differences in local prey availability, dietary quality, or predation efficiency (Britt, Hicks \& Bennett, 2006), or a complex spatio-temporal interaction that is reflected in micro-geographic diet variation, a pattern common in garter snakes (Seigel, 1996). The body condition differences among years and localitions within species would be evidence that the patterns found are likely just based on prey availability or climatic constraints on feeding as temporarily fluctuating assimilation rates.

Morphological plasticity induced by diet is extensively documented, especially for natricine snakes (e.g., Krause, Burghardt \& Gillingham, 2003; Vincent et al., 2009; Hampton, 2013), and some involve comparisons of snake populations separated by geographic distances. In this study, location and diet were a significant overall factor influencing body size and body condition in garter snakes. The diet has differential effects on $T$. eques and T. melanogaster. Both snakes eating fish (Cuitzeo populations) have shorter or lighter relative body sizes, but they respond differentially in their body condition to the piscivorous diet. The generalist T. eques have relative best body condition at Cuitzeo, while the specialist $T$. melanogaster apparently does not present significant differences in body condition between the piscivorous population versus other prey. The differences across the two localities may not be strictly due to diet, as is suggested by the fact that juveniles and adult males and females in the two sites show particular differences in any measure of body size (SVL and mass).

Sympatric and closely related species are expected to exhibit a similar body condition due to the ecological similarities that impose common selective pressures, as suggested by the study in closely related and sympatric garter snakes T. melanogaster and T. eques with similar patterns of neonate body condition (Manjarrez \& San-Roman-Apolonio, 2015). However, we cannot assume that the garter snakes we studied make similar use of local energy supplies, which may vary according to intra-interspecific competition and available resources (Congdon, 1989), especially on prey availability (Krause, Burghardt \& Gillingham, 2003).

Growth and body condition in snakes may reflect intraspecific competition intensity that would correspond to availability and allocation of energy (Bronikowski, 2000; Bronikowski \& Arnold, 1999; Blouin-Demers, Prior \& Weatherhead, 2002). This is especially applicable for female garter snakes because they are generally heavier bodied and have greater reproductive energy demands than males (Naulleau \& Bonnet, 1996; Shine et al., 2001; Blouin-Demers \& Weatherhead, 2007).

For most of the locations in this study, the sex ratio was biased towards females, a common pattern in other species of Thamnophis (Parker \& Plummer, 1987); however, the basic question is whether the variation is true, displaying actual population structure, or is false, reflecting different sexual behavioral traits that can influence catchability of males and females at some locations (Parker \& Plummer, 1987). The sex ratio of the present locations of the garter snakes studied may not be accurate; in this sense, our conclusions about the 
geographical differences of the corporal condition should be considered with caution due to the sexual variability of the body condition between locations.

Ontogenic differences in body condition can result from differential resource use. For example, studies on T. melanogaster, T. eques, and T. scalaris have reported intraspecific differences in the diet of snakes, such as the changing of aquatic invertebrate to terrestrial vertebrate prey between small and large snakes (Macias-Garcia \& Drummond, 1988; Manjarrez, Venegas-Barrera \& García-Guadarrama, 2007; Manjarrez, Macías García \& Drummond, 2013; Manjarrez, Pacheco-Tinoco \& Venegas-Barrera, 2017). This suggests different trade-off strategies between growth rate and body mass for resource allocation among sites, according to sex (King, 1989; King, 1997; Krause, Burghardt \& Gillingham, 2003) and ontogenic reproductive status (Naulleau \& Bonnet, 1996; Lind \& Beaupre, 2015). This trade-off has been sparsely studied in neonate snakes (i.e., Nerodia sipedon and Elaphe obsolete; (Weatherhead et al., 1999; Blouin-Demers \& Weatherhead, 2007).

Another reason for geographic variation in the body condition of juvenile and adult snakes includes geographic variation in the percentage of juveniles and adults in the population. For T. melanogaster, $94 \%$ of juveniles and $76 \%$ of adults were collected from Cuitzeo; while for T. eques $70 \%$ of juveniles and $77 \%$ of adults were collected Lerma. In T. scalaris locations, this age bias was less evident, with collection percentages of juveniles ranging from $17 \%$ to $31 \%$ by location, and $15 \%$ to $27 \%$ for adults.

According to our results, the models propose different paths for population fitness of each garter snake species assuming the current body condition. In this way, the future scenario responds according to the local geographic variation of each population; however, this prediction is difficult to rely upon because environmental fluctuations can be unpredictable, and changes in the climate, vegetation, topography, and land use variables will reduce the future potential distribution of these three garter snakes, as has been predicted in González-Fernández et al. (2018).

Another important pattern in this study is the interspecific difference of body condition within the same location. For example, in Cuitzeo, the body condition of T. eques is good, and in Lerma it is poor, while in T. melanogaster the body condition is inverse; poor in Cuitzeo and good in Lerma. This difference could be explained by interspecific differences in resource use and its differential microdistribution. In this sense, T. eques is a generalist in its diet, ingesting aquatic and terrestrial prey, while T. melanogaster is a specialist ingesting only aquatic prey. The majority of specialist-generalist trade-offs are related with wide ecological traits that result in distinct performance between specialists and generalists (Drummond, 1983; Futuyma \& Moreno, 1988). If these species exploit different foraging environments, it is likely that they are exposed to different environmental conditions. For example, Cuitzeo is a permanent lake that offers a constant aquatic foraging environment for the aquatic specialist T. melanogaster, while Lerma is a wetland environment, more suitable for the aquatic-terrestrial T. eques, a differential pattern that is reflected in the interspecific differential body condition within both locations. In this sense, the interspecific differences of the body condition can be a reflection of the phenotypic plasticity of both garter snakes, because the geographical difference in the diet is reflected in the local differences of body condition. 
The morphological differences found in these studies reflected phenotypic plasticity, rather than genotypic differences, although the relative function of genotype, ontogeny, and sex in the presence of this plasticity could only be inquired through future studies. Also, further exploration, including a larger sample size by local diet, is required.

\section{CONCLUSIONS}

In conclusion, our analyses suggest that traits associated with body condition of sympatric Mexican garter snakes T. eques, T. melanogaster, and T. scalaris in the Central Mexico Highlands reveal a pattern of microgeographical variation among local populations that differ little by ontogenic reproductive status, and therefore sex has little or no influence on body condition in these garter snakes. The diet has differential effects on T. eques and $T$. melanogaster in traits associated with body condition.

\section{ACKNOWLEDGEMENTS}

We thank all of the students of the Evolutionary Biology Laboratory for their assistance in the field and laboratory work. Ruthe J. Smith provided comments and corrections regarding the manuscript. EVF is grateful to the graduate program "Maestria en Ciencias Agropecuarias y Recursos Naturales" of "Universidad Autonoma del Estado de Mexico" and to the "Consejo Nacional de Ciencia y Tecnología". Moral support to JM was provides by Carmen Zepeda, Javier and Mariana Manjarrez-Zepeda.

\section{ADDITIONAL INFORMATION AND DECLARATIONS}

\section{Funding}

This study received funding resources of the Universidad Autónoma del Estado de México (Number 4047/2016SF). The funders had no role in study design, data collection and analysis, decision to publish, or preparation of the manuscript.

\section{Grant Disclosures}

The following grant information was disclosed by the authors:

Universidad Autónoma del Estado de México: 4047/2016SF.

\section{Competing Interests}

The authors declare there are no competing interests.

\section{Author Contributions}

- Erika Valencia-Flores performed the experiments, analyzed the data.

- Crystian S. Venegas-Barrera analyzed the data, prepared figures and/or tables, authored or reviewed drafts of the paper, approved the final draft.

- Victor Fajardo contributed reagents/materials/analysis tools, authored or reviewed drafts of the paper.

- Javier Manjarrez conceived and designed the experiments, analyzed the data, contributed reagents/materials/analysis tools, prepared figures and/or tables, authored or reviewed drafts of the paper, approved the final draft. 


\section{Animal Ethics}

The following information was supplied relating to ethical approvals (i.e., approving body and any reference numbers):

This study received the approval of the ethics committee of the Universidad Autónoma del Estado de México (Number 4047/2016SF).

\section{Field Study Permissions}

The following information was supplied relating to field study approvals (i.e., approving body and any reference numbers):

This study received the approval of field permit \#07164 from the Secretaria del Medio Ambiente y Recursos Naturales.

\section{Data Availability}

The following information was supplied regarding data availability:

The raw data are available in a Supplemental File.

\section{Supplemental Information}

Supplemental information for this article can be found online at http://dx.doi.org/10.7717/ peerj.6601\#supplemental-information.

\section{REFERENCES}

Ashton KG. 2001. Body size variation among mainland populations of the western rattlesnake (Crotalus viridis). Evolution 55:2523-2533

DOI 10.1111/j.0014-3820.2001.tb00766.x.

Blouin-Demers G, Prior KA, Weatherhead PJ. 2002. Comparative demography of black rat snakes (Elaphe obsoleta) in Ontario and Maryland. Journal of Zoology 256:1-10 DOI 10.1017/S0952836902000018.

Blouin-Demers G, Weatherhead PJ. 2007. Allocation of offspring size and sex by female black ratsnakes. Oikos 116:1759-1767 DOI 10.1111/j.0030-1299.2007.15993.

Bonnet X, Shine R, Naulleau G, Vallas-Vacher M. 1998. Sexual dimorphism in snakes: different reproductive roles favour different body plans. Proceedings of the Royal Society B 265:179-183 DOI 10.1098/rspb.1998.0280.

Britt E, Hicks J, Bennett AF. 2006. The energetic consequences of dietary specialization in populations of the garter snake, Thamnophis elegans. The Journal of the Experimental Biology 209:3164-3169 DOI 10.1242/jeb.02366.

Bronikowski AM. 2000. Experimental evidence for the adaptive evolution of growth rate in the garter snake Thamnophis elegans. Evolution 54:1760-1767 DOI 10.1111/j.0014-3820.2000.tb00719.x.

Bronikowski AM, Arnold SJ. 1999. The evolutionary ecology of life history variation in the garter snake Thamnophis elegans. Ecology 80:2314-2325 DOI 10.2307/176912.

Brown GP, Weatherhead PJ. 1997. Effects of reproduction on survival and growth of female northern water snakes, Nerodia sipedon. Canadian Journal of Zoology 75:424-432 DOI 10.1139/z97-052. 
Burghardt GM, Schwartz JM. 1999. Geographic variations on methodological themes in comparative ethology: a natricine snake perspective. In: Foster SA, Endler JA, eds. Geographic variation in behavior: perspectives on evolutionary mechanisms. Oxford: Oxford University Press, 69-94.

Catherine AD, LeMaster MP, Lutterschmidt DI. 2018. Physiological correlates of reproductive decisions: relationships among body condition, reproductive status, and the hypothalamus-pituitary-adrenal axis in a reptile. Hormones and Behavior 100:1-11 DOI 10.1016/j.yhbeh.2018.02.004.

Congdon JD. 1989. Proximate and evolutionary constraints on energy relations of reptiles. Zoology Physiological 62:356-373 DOI 10.1086/physzool.62.2.30156175.

De Queiroz A, Lawson R, Lemos-Espinal JA. 2002. Phylogenetic relationships of North American Garter snakes (Thamnophis) based on four mitochondrial genes: how much DNA sequence is enough? Molecular Phylogenetics and Evolution 22:315-329 DOI 10.1006/mpev.2001.1074.

Drummond H. 1983. Aquatic foraging in garter snakes: a comparison specialist and generalist. Behaviour 86:1-30 DOI 10.1163/156853983X00543.

Drummond H, Macías García C. 1989. Limitations of a generalist: a field comparison of foraging snakes. Behaviour 108:23-43 DOI 10.1163/156853989X00033.

Falk BG, Snow RW, Reed RN. 2017. A validation of 11 body-condition indices in a giant snake species that exhibits positive allometry. PLOS ONE 12:e018079 DOI 10.1371/journal.pone.0180791.

Fitch HS. 1987. Collecting and life history techniques. In: Seigel RA, Collins JT, Novak SS, eds. Snakes: ecology and evolutionary biology. New York: Macmillan, 143-164.

Flores-Villela O, Canseco-Márquez L, Ochoa-Ochoa L. 2010. Geographic distribution and conservation of the herpetofauna of the highlands of Central Mexico. In: Wilson LD, Towsend JH, Johnson JD, eds. Conservation of mesoamerican amphibians and reptiles. Utah: Eagle Mountain Publishing Co, 303-321.

Futuyma DJ, Moreno G. 1988. The evolution of ecological specialization. Annual Review of Ecology, Evolution, and Systematics 19:207-233

DOI 10.1146/annurev.es.19.110188.001231.

González-Fernández A, Manjarrez J, García-Vázquez U, D’Addario M, Sunny A. 2018. Present and future ecological niche modeling of garter snake species from the TransMexican Volcanic Belt. PeerJ 6:e4618 DOI 10.7717/peerj.4618.

Guo P, Liu Q, Xu Y, Jiang KM, Ding L, Pyron RA, Burbrink FT. 2012. Out of Asia: natricinae snakes support the Cenozoic Beringian Dispersal Hypothesis. Molecular Phylogenetics and Evolution 63:825-833 DOI 10.1016/j.ympev.2012.02.021.

Hampton PM. 2013. Feeding in natricines: relationships among feeding morphology, behavior, performance and preferred prey type. Journal of Zoology 290:215-224 DOI 10.1111/jzo.12029.

Hayes J, Shonkwiler J. 2001. Morphometric indicators of body condition: worthwhile or wishful thinking? In: Speakman JR, ed. Body composition analysis of animals: a handbook of non-destructive methods. Cambridge: Cambridge University Press, 8-38. 
King RB. 1989. Body size variation among island and mainland snake populations. Herpetologica 45:335-346.

King RB. 1997. Variation in Brown snake (Storeria dekayi) morphology and scalation: sex, family, and microgeographic differences. Journal of Herpetology 31:335-346 DOI $10.2307 / 1565661$.

Kissner KJ, Weatherhead PJ. 2005. Phenotypic effects on survival of neonatal northern watersnakes Nerodia sipedon. Journal of Animal Ecology 74:259-265 DOI 10.1111/j.1365-2656.2005.00919.

Koyama T, Ito H, Kakishima S, Yoshimura J, Cooley JR, Simon C, Sota T. 2015. Geographic body size variation in the periodical cicadas Magicicada: implications for life cycle divergence and local Adaptation. Journal of Evolutionary Biology 28:1270-1277 DOI 10.1111/jeb.12653.

Krause MA, Burghardt GM, Gillingham JC. 2003. Body size plasticity and local variation of relative head and body size sexual dimorphism in Garter Snakes Thamnophis sirtalis. Journal of Zoology 261:399-407 DOI 10.1017/S0952836903004321.

Kurzava LM, Morin PJ. 1994. Consequences and causes of geographic variation in the body size of a keystone predator, Notophthalmus viridescens. Oecologia 99:271-280 DOI 10.1007/BF00627739.

Lind CM, Beaupre SJ. 2015. Male snakes allocate time and energy according to individual energetic status: body condition, steroid hormones, and reproductive behavior in timber rattlesnakes, Crotalus horridus. Physiological and Biochemical Zoology 88:624-633 DOI 10.1086/683058.

Macias-Garcia C, Drummond H. 1988. Seasonal and ontogenetic variation in the diet of the Mexican garter snake, Thamnophis eques in Lake Tecocomulco, Hidalgo. Journal of Herpetology 2:129-134.

Madsen T, Shine R. 1993. Costs of reproduction in a population of European adders. Oecologia 94:488-495 DOI 10.1007/BF00566963.

Manjarrez J. 1998. Ecology of the Mexican Garter snake (Thamnophis eques) in Toluca, Mexico. Journal of Herpetology 32:464-468 DOI 10.2307/1565469.

Manjarrez J, Macías García C, Drummond H. 2013. Variation in the diet of the Mexican black-bellied garter snake Thamnophis melanogaster: importance of prey availability and snake body size. Journal of Herpetology 47:413-420 DOI 10.2307/1948469.

Manjarrez J, Pacheco-Tinoco M, Venegas-Barrera CS. 2017. Intraspecific variation in the diet of the Mexican garter snake Thamnophis eques. PeerJ 5:e4036 DOI 10.7717/peerj.4036.

Manjarrez J, San-Roman-Apolonio E. 2015. Timing of birth and body condition in neonates of two gartersnake species from Central Mexico. Herpetologica 71:12-18 DOI 10.1655/HERPETOLOGICA-D-13-00098.

Manjarrez J, Venegas-Barrera CS, García-Guadarrama T. 2007. Ecology of the Mexican alpine blotched garter snake (Thamnophis scalaris). Southwestern Naturalist 52:258-262 DOI 10.1894/0038-4909(2007)52[258,EOTMAB]2.0.CO;2.

McVay JD, Carstens B. 2013. Testing monophyly without well-supported gene tress: evidence from multi-locus nuclear data conflicts with existing taxonomy in the 
snake tribe Thamnophiini. Molecular Phylogenetics and Evolution 68:425-431

DOI 10.1016/j.ympev.2013.04.028.

Miller DA, Clark WR, Arnold SJ, Bronikowski AM. 2011. Stochastic population dynamics in populations of western terrestrial garter snakes with divergent life histories. Ecology 92:1658-1671 DOI 10.1890/10-1438.1.

Naulleau G, Bonnet X. 1996. Body condition threshold for breeding in a viviparous snake. Oecologia 107:301-306 DOI 10.1007/BF00328446.

Parker WS, Plummer MV. 1987. Population ecology. In: Siegel R, Collins J, Novak S, eds. Snakes: ecology and evolutionary biology. Caldwell: The Blackburn Press, 253-301.

Rollings N, Uhrig EJ, Krohmer RW, Waye HL, Mason RT, Olsson M, Whittington CM, Friesen CR. 2017. Age-related sex differences in body condition and telomere dynamics of red-sided garter snakes. Proceedings of the Royal Society B 284:20162146 DOI 10.1098/rspb.2016.2146.

Rossman DE, Ford NB, Seigel RA. 1996. The Garter snakes: evolution and ecology. Norman: University of Oklahoma Press.

Seigel RA. 1996. Ecology and conservation of garter snakes: masters of plasticity. In: Rossman DA Ford NB, Seigel RA, ed. The Garter snakes. Evolution and ecology. Norman: University of Oklahoma Press, 55-89.

Shine R. 1993. Sexual dimorphism in snakes. In: Seigel RA, Collins JT, eds. Snakes: ecology and behavior. New York: McGraw-Hill, 49-86.

Shine R. 1994. Sexual dimorphism in snakes revised. Copeia 1994:326-346 DOI 10.2307/1446982.

Shine R, Lemaster MP, Moore IT, Olsson MM, Mason RT. 2001. Bumpus in the snake den: effects of sex, size, and body condition on mortality of red-sided Garter snakes. Evolution 55:598-604 DOI 10.1554/0014-3820(2001)055[0598,BITSDE]2.0.CO;2.

Sivan J, Kam M, Hadad S, Degen AA, Rosenstrauch A. 2015. Body size and seasonal body condition in two small coexisting desert snake species, the Saharan sand viper (Cerastes vipera) and the crowned leafnose (Lytorhynchus diadema). Journal of Arid Environments 114:8-13 DOI 10.1016/j.jaridenv.2014.10.013.

Vincent SE, Brandley MC, Herrel A, Alfaro ME. 2009. Convergence in trophic morphology and feeding performance among piscivorous natricine snakes. Journal of Evolutionary Biology 22:1203-1211 DOI 10.1111/j.1420-9101.2009.01739.x.

Weatherhead PJ, Brown GP. 1996. Measurement versus estimation of condition in snakes. Canadian Journal of Zoology 74:1617-1621 DOI 10.1139/z96-179.

Weatherhead PJ, Brown GP, Prosser MR, Kissner KJ. 1999. Factors affecting neonate size variation in northern water snakes, Nerodia sipedon. Journal of Herpetology 33:577-589 DOI 10.2307/1565574.

Yom-Tov Y, Geffen E. 2006. Geographic variation in body size: the effects of ambient temperature and precipitation. Oecologia 148:213-218

DOI 10.1007/s00442-006-0364-9. 